\title{
Térségi gazdaságfejlesztés és okos régió térinformatikai támogatással
}

\author{
Niklasz László - Varga-Ötvös Béla
}

DOI: https://doi.org/10.30921/GK.70.2018.1.5

\section{Elözmények}

Korábban részletesen beszámoltunk [1] a digitalizáció és az intelligens (okos) város építésének helyzetérôl Törökbálinton. A beszámolóból nyilvánvalóvá vált, hogy a digitalizáció elterjedtsége a város életében magas szintet ért el, és ez megteremtette az alapját az okos város létrehozásának.

Törökbálint digitális város koncepciójában találkozik egymással a technológiai innováció, a gazdasági versenyképesség-növelés, a fenntarthatóság és az emberközpontú városvezetés. A hivatkozott tanulmány megállapította, hogy az okos technológiák alkalmazásának, összekapcsolásának folyamata elkezdôdött, és a város Gazdasági Programja által lefedett ötéves (20152019) ciklus 2016-2017. évi tervei fokuszálnak elsố sorban erre a tevékenységre. Természetesen, ezen technológiák alkalmazásához innovatív térinformatikai megoldásokra is szükség van.

A digitális átalakulás folyamatát meggyorsította, hogy Törökbálint 20162017-ben mintegy 1 millió euro támogatással megvalósíthatta a „Helyi és kistérségi gazdaságfejlesztés alapjainak lerakása tudástranszferrel és önkormányzati kapacitásfejlesztéssel" elnevezésú projektet (továbbiakban NORMA projekt), amit a Norvég Finanszírozási Mechanizmus támogatott, és norvég, illetve magyar partnerekkel való együttmúködésben valósult meg. Mivel a projekt kiemelt jelentôséget tulajdonított a térinformatika mint interdiszciplináris elem alkalmazásának, mind a gazdaságfejlesztés, mind az okos város létrehozása tekintetében, a tudástranszfer támogatására a Magyar Térinformatikai Társaság (HUNAGI) is partnerként múködött közre a projektben.

A téma részletesebb kifejtése elôtt szeretnénk kiemelni, hogy a NORMA-projekt keretében kialakított „Törökbálint és térsége kistérségi gazdaságfejlesztési modell - koncepció és stratégia” megállapítja: „az okos várost megelôzốen elôbb az okos lakos, az okos településhasználó létrejöttének kell megtörténnie, hogy az ember ne csak alkalmazó és fogyasztó legyen, mert akkor az események követôje és nem alakítója”.

Említésre méltó még, hogy a projekt megvalósításával szinte egy idôben igazolva, hogy a projekt célkitúzései aktuálisak - megjelent a 1456/2017. (VII. 19.) korm.-határozat, melynek 20. pontja szerint a Kormány „kiemelkedöen fontosnak tartja a helyi, települési és térségi közösségek digitális fejlesztési programjainak, illetve az Okos Város (Smart City) fejlesztések támogatását, ezért elrendeli egy Okos Város munkacsoport, illetve Okos Város és Okos Térség közigazgatási mintaprojekt létrehozását, valamint az Okos Város megoldások megjelenitését a kormánytisztviselôi és köztisztviselối képzésekben;...”.

Mindezek ismeretében fejtjük ki részletesebben a továbbiakban tanulmányunk témakörét.

\section{A helyi és kistérségi gazdaságfejlesztés koncepciója}

A helyi és kistérségi gazdaságfejlesztés egyik meghatározó indítéka egy társadalompolitikai cél elérése, nevezetesen a helyben élők jólétének növelése, amelynek eszköze a versenyképesség javítása, alapja pedig az innovációs képesség.

A gazdaságfejlesztési koncepció másik alapvetố tényezôje a befektetések támogatása a térségben.

A gazdaságfejlesztés harmadik kulcseleme a digitalizáció, amely egyúttal a versenyképesség legfontosabb elemévé vált a múszaki fejlôdés során. A magyar gazdaság versenyképességének előfeltétele, hogy a meghatározó szektor, a mikro-, kis- és középvállalkozások, illetve a munkavállalók megfelelő, az átlagot meghaladó digitális kompetenciával rendelkezzenek

Az önkormányzat szemszögéból nézve ez az önkormányzati ügymenet, szolgáltatások digitalizációját - azaz az e-közigazgatás bevezetését - jelenti.

A megközelítés egyértelmúen „stratégiai", azaz nem bemutatni kell egy kistérség gazdaságát, hanem feltárni azokat a mozgatórugókat, amelyek kihasználására fejlesztési stratégia épülhet.

A modell koncepcionális elemei a következôk:

- Hosszú távú gazdaságfejlesztési modell - stratégia - megalkotása, mely térségi együttmúködésre alapoz (alulról jövố regionális gazdaságfejlesztési stratégia).

- Az egyes települések és ezzel együtt a kistérség versenyképességének növelése, kihasználva a helyi értékeket, lehetôségeket. Klaszter-alapú gazdaságfejlesztés.

- A fentiekre építve befektetés-ösztönzési kulcsmodell kialakítása.

- Széles körú digitalizáció és a helyi lakosságnak erre való felkészítése mint gazdaságfejlesztési koncepcionális elem.

A fentiek lehetôvé teszik, hogy létrejöjjön több település térben és idôben újszerú, rugalmas gazdaságfejlesztési együttmúködése. A flexibilitás mellett a modell alapvetô tulajdonsága a nyitottság, ami azt jelenti, hogy az Okos Régióba tömörült településekhez a jövôben bármikor csatlakozhat egy-egy újabb, akár más megyében, országrészben lévố település; és akkor is múködôképes a rendszer, ha egy település kilép belőle. A rugalmasság vonatkozik arra is, hogy a modell a visszacsatolások által bármikor változtatható, fejleszthetô, továbbá cél, hogy a modell képes legyen befogadni és hasznosítani a legkülönbözóbb finanszírozási forrásokat és gazdasági partnereket. Ezt a települések közötti rugalmas és nyitott gazdaságfejlesztési 
szervezôdést „mozaiktérség”-nek nevezzük, mivel átlépi (meghaladja) a hagyományos gazdaságföldrajzi vagy közigazgatási alapú szervezôdéseket. A modellben résztvevố térségi önkormányzatok „térben és tér felett”, egyfajta mozaiktérségben múködnek együtt. Korunkban ugyanis már nem szükséges a közvetlen földrajzi szomszédság, mivel az elektronizáció lehetôvé teszi az együttmúködést a fizikailag elkülönült egységek között is az internet és IT-rendszerek segítségével. Valódi 21. századi formáról van szó, hiszen ma már a „felhôben” is az elektronizáció adta lehetôségek kihasználásával - létrejöhet szoros gazdasági együttmúködés és munkamegosztás települések, cégek, intézmények között.

\section{Kistérségi gazdaságfejlesztési modell}

A törökbálinti kistérségi modell Törökbálint, Diósd, Pusztazámor, Sóskút és Tárnok települések alkotta mozaiktérség gazdaságfejlesztési együttmûködését rendszerezi 21 . századi eszközök alkalmazásával. A mozaiktérség gazdaságfejlesztési szervezôdésének modellnevet is adtunk: „5T-modell” - az Okos Régió (Smart Region)”. Az elnevezésben megjelenik az öt alapító település, a térségfejlesztési, települési koordináció, és egyben utal korunk negyedik ipari (gazdasági) forradalmára, a száz évvel ezelôtti ipari forradalom emblematikus termékének, a Ford T-modellnek a felidézésével.

Az ún. „5T-modell” - az Okos Régió, az okos város gondolatának továbbfejlesztésére épül, az alulról felfelé építkezés elvét alkalmazva.

Az okos város (Smart City) olyan települést takar, mely a rendelkezésre álló technológiai lehetôségeket (elsôsorban az infokommunikációs technológiát - IKT) olyan innovatív módon használja fel, amely elôsegíti egy jobb, diverzifikáltabb és fenntarthatóbb városi környezet kialakítását. Egy várost akkor nevezhetünk „okosnak”, ha az emberi tôkébe, a hagyományos infrastrukturális elemekbe (pl. közlekedés, energiaellátás), valamint a modern IKT-infrastruktúrába történő befektetései ösztönzik és hajtják a fenntartható gazdasági fejlôdést, valamint tovább növelik az életszínvonalat, miközben a természeti eróforrásokkal is észszerû́en gazdálkodik. Az okos város tehát az okos technológiát úgy használja, hogy a város infrastrukturális rendszerei és szolgáltatásai sokkal jobban kapcsolódjanak egymáshoz, intelligensebbek és hatékonyabbak legyenek.

Alapvetố szempont, hogy a gazdaságfejlesztési modell megvalósításában a digitális eszközök és megoldások elôtérbe kerüljenek. Nélkülözhetetlenek a letölthető e-alkalmazások, az okosabbnál okosabb elektronikai készülékek és a térinformációk, ugyanakkor a törökbálinti mozaiktérség településeit emberek és közösségek élik, éltetik és használják.

Az eszközök „programozott tudása” nem vezérelheti a gazdasági és közösségi együttmúködési folyamatokat. A veszély nagy, mivel kész elektronikai rendszerek kínálnak tevékenységi pályákat (lásd sokan már a rokonlátogatást és a rutinvásárlásokat is GPSvezérléssel bonyolítják - a tévutak széles lehetôségének kínálatával).

Következtetés: elôbb az okos lakos (Smart Citizen), az okos településhasználó létrejöttének kell megtörténnie. Az ember ne csak alkalmazó és fogyasztó legyen, mert akkor az események követôje és nem alakítója. Az eszközt idomítsuk az emberhez, közösséghez és ne fordítva. Ne legyen kényszer alkalmazkodni a technológiai rendszerekhez.

Az okos lakos létrejöttét támogatták a NORMA-projekt keretében kifejlesztett e-learning tananyagok és az élethosszig tartó tanulási kampány, továbbá egy térségi oktatási portál létrehozása.

\subsection{Az Okos Régió \\ kialakításának elốnyei}

Miként az okos város, úgy az Okos Régió is új perspektívát vetít ki a jövőbe. Új település- és vidékfejlesztési reneszánsz lehetôségét kínálja fel. A fó eszközei: a helyi adottságok kihasználása, együttmúködés cégek és önkormányzatok között, „térségi közös piac”, digitalizáció (IT-eszközök használata), piaci kezdeményezőképesség.
Az Okos Régió és a digitalizáció településhasználati lehetôségei, pozitív hatásai:

- Az információ, a tudás, az anyag, a termék házhoz jön.

- A távmunka, távoktatás, az e-ügyintézés, az online vásárlás, az elektronikus együttmúködés egyaránt erôforrás-optimalizáló hatású.

- Az automatizálás, robotika, digitalizáció terjedésével visszaszorul a tömegmunka, ami teret nyit az emberi kreativitás számára.

- Ezzel a személy, a közösség és a hely felértékelôdik. Előnybe kerülnek a lakó-, a munka-, a közéleti és a rekreációs terek kompakt egységei. Átalakul a közlekedési igény lokális szerkezete, a helyi és térségi forgalom hangsúlyosabbá válhat

- A helyben maradás erôsödésével növekszik a helyi költés, amely helyi kínálatbővülést generál, kezdetben a szolgáltatásokban, a kiskereskedelemben és a vendéglátásban. A folyamat munkahelyeket, majd gazdasági profilbővülést eredményez. A fejlôdés eredményeként helyi és térségi piac alakul ki.

- Megerôsödnek a helyi és térségi közösségek, szomszédságok.

\section{A térinformatika szerepe a gazdaságfejlesztésben}

A térinformatika interdiszciplináris voltából következik, hogy jelentôs szerepet játszik a gazdaságfejlesztésben is. A területfejlesztés és ehhez szorosan kapcsolódó településrendezés alapozza meg a településfejlesztést. Ennek alapvetố dokumentumai a településfejlesztési koncepció és az integrált településfejlesztési stratégia (Törökbálint mindkettôvel rendelkezik). A településrendezés pedig a településszerkezeti tervre és a szabályozási tervekre épül. Ez utóbbiak térinformatikai eszközökkel jönnek létre. Az 1. ábra Törökbálint digitális településszerkezeti tervének egy részletét mutatja be.

Helyi és kistérségi gazdaságfejlesztés, befektetésösztönzés nem létezhet naprakész rendezési tervek és abból történố térinformatikai szolgáltatások nélkül. Tehát az érintett önkormányzatok akkor tudnak 


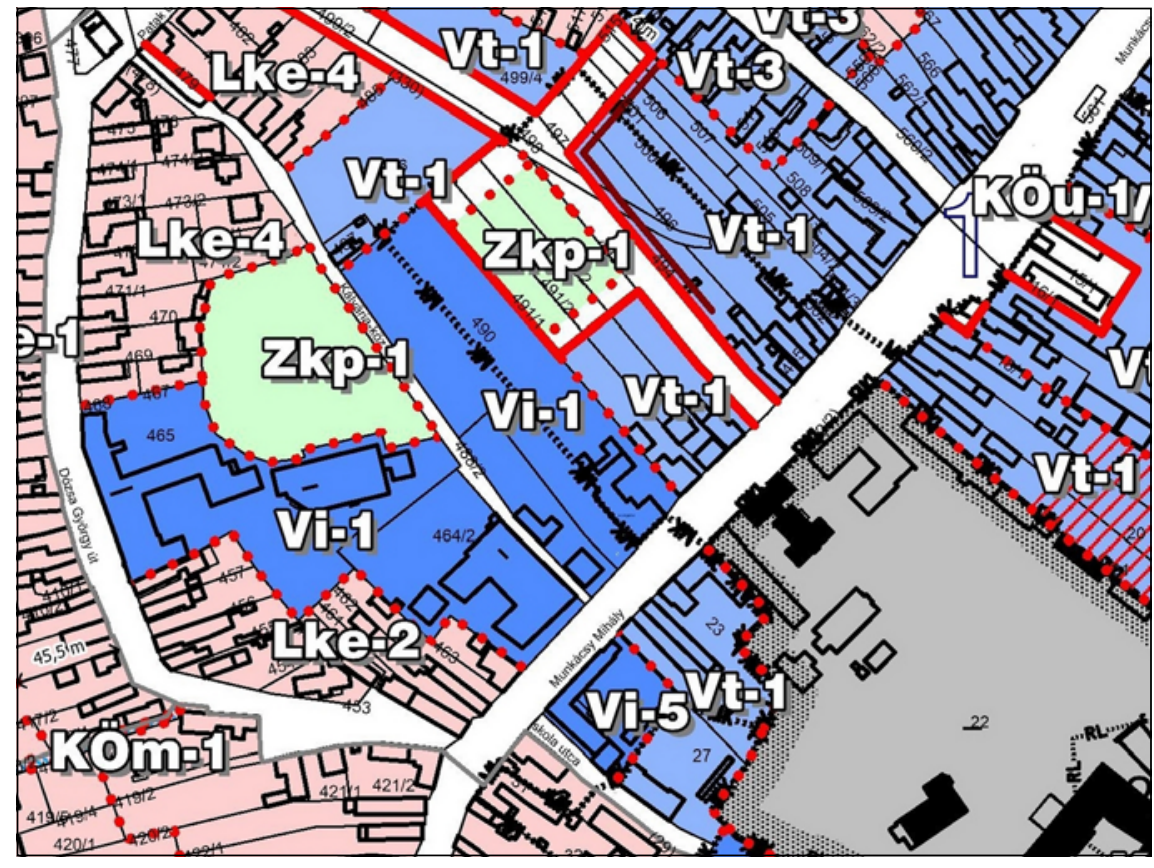

1. ábra. Törökbálint településszerkezeti terve - részlet

hatékony gazdaságfejlesztést végezni, ha ilyen informatikai támogatással rendelkeznek.

\subsection{Térinformatika a helyi gazdaságfejlesztésben}

Az elôzốekben kiemeltük, hogy a hatékony önkormányzati gazdaságfejlesztés fontos eleme egy fejlett térinformatikai rendszer rendelkezésre állása. A második fejezetben megállapítottuk, hogy a gazdaságfejlesztés harmadik kulcseleme a digitalizáció, mely egyúttal a versenyképesség legfontosabb elemévé vált az utóbbi idôben. Ez azt is jelenti, hogy a gazdaságfejlesztéshez digitális információkra és rendszerekre van szükségünk.

Az előzőekben megfogalmazott igényeket elégíti ki a Törökbálinton kifejlesztett önkormányzati döntéstámogatási információs rendszer (DTIR), amely egy térinformatikai alapú vezetôi információs rendszer. A DTIR az [1] tanulmányban leírt rendszer továbbfejlesztett változata.

Településrendezés, településfejlesztés, befektetéstámogatás, helyi infrastrukturális beruházások tervezése nem lehetséges megfelelố döntés-elôkészítés nélkül. A megalapozott döntés-elôkészítéshez pedig széles körú és naprakész információszolgáltatásra van szüksége az önkormányzat képviselő-testületének és a polgármesteri hivatal szakembereinek. A DTIR ezekhez a fejlesztési döntésekhez az alábbi releváns téradatkészleteket és szolgáltatásokat nyújtja:

- e-ingatlan-nyilvántartás,

- e-közmúnyilvántartás,

- rendezési tervek (településszerkezeti és szabályozási tervek),

- magassági adatok és DDM,

- ortofotó,

- utcatérkép,

- ingatlanvagyon-kataszter.

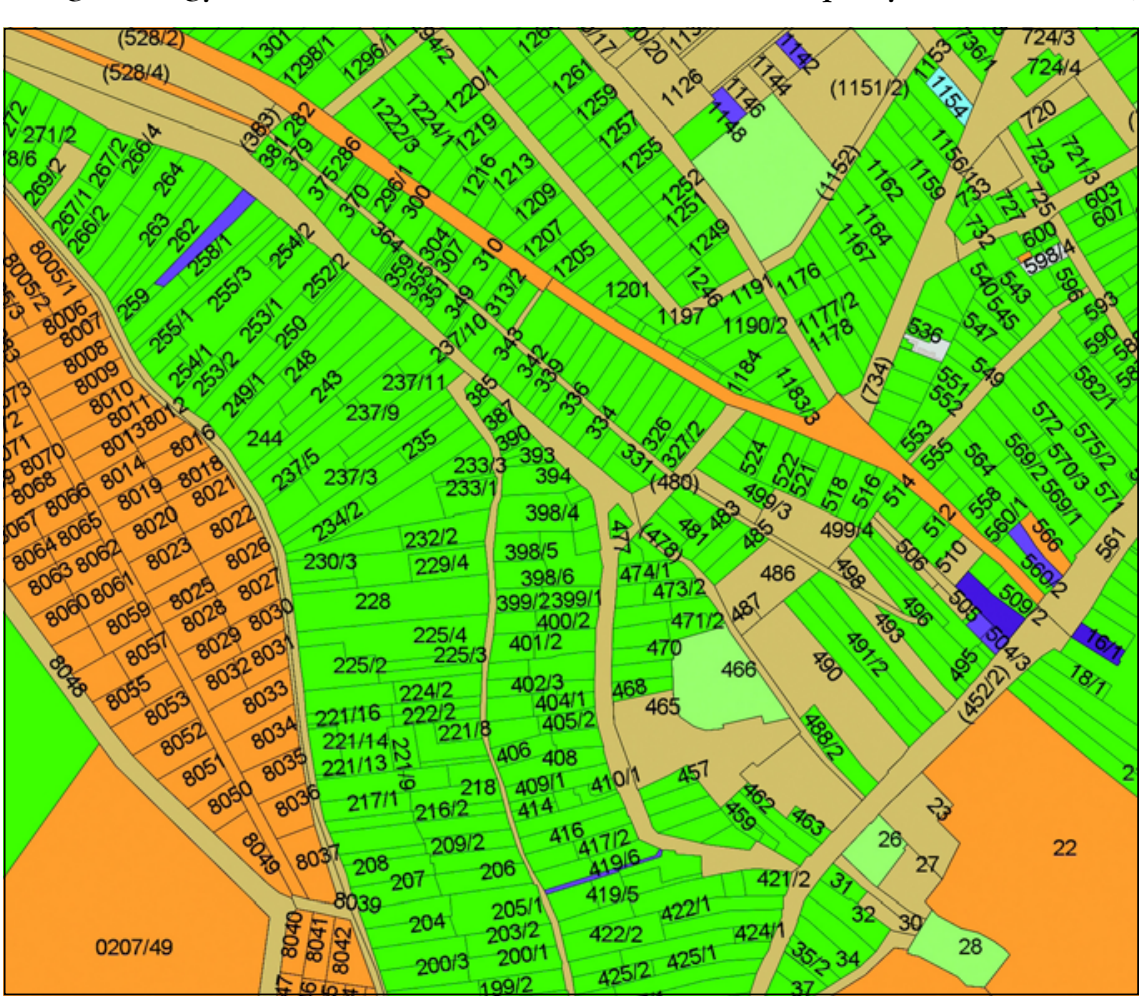

2. ábra. Törökbálint ingatlanvagyon-katasztere - részlet
A döntési folyamat papírmentesen zajlik, mind a testületi elôterjesztések, mind a határozatok elektronikus úton születnek.

\subsection{Térinformatika a térségi gazdaságfejlesztésben}

Az elốzóekben jeleztük, hogy a gazdaságfejlesztési koncepció egyik meghatározó eleme a befektetések támogatása. Ennek egyik eleme esetünkben a befektetésösztönzési stratégia kialakítása (lásd [5] alatt). Másik eleme pedig egy kistérségi befektetéstámogatási információs rendszer (KIBIR) létrehozása volt, amelyben jelentôs szerepet játszott a térinformatika.

A KIBIR célja mindazon adatok, információk egységes rendszerbe szervezése, amelyek

- egyrészt ahhoz szükségesek, hogy az adott önkormányzat - az igazgatási területe vonatkozásában - áttekinthető képet kaphasson a befektetésre alkalmas területekrốl, azok jellemzóirôl, és helyi vagy térségi gazdaságfejlesztést célzó döntéseket készíthessen elő, illetve hozhasson,

- másrészt a befektetôk számára releváns információkat (pl.: földrajzi, építési, közmú- és közlekedési infrastruktúra), nyújtson a számukra alkalmas telephely kiválasztásához, 
az adott település értéktárának, ingatlanportfoliójának és befektetés-ösztönzô adottságainak információs rendszerben való kezelése és elérése révén.

A rendszer elsô lépésben mikrotérségi szinten, 4-5 település adatait kezeli, oly módon, hogy további települések adataival bốvíthetố legyen, akár mozaikszerúen is. Az alkalmazás egy webalapú portál, térinformatikai alkalmazáshoz való kapcsolódással. A 3. ábra egy kiválasztott település portfóliójának nyitóoldalát mutatja.

A KIBIR az adott települések ingatlanportfolióira épül, amelyek az egyes - befektetésre kínált - ingatlanok leíró adatait és az adott ingatlanhoz csatolt fotókat, rajzokat tartalmazzák.
A portfólióba kerülố minden egyes ingatlan egy ún. adatlappal rendelkezik, mely a befektetôk számára fontos információkat tartalmazza. Az adatlap magyar, angol és német nyelven is megjelenik.

Egy kiválasztott ingatlan (lásd 4. ábrát) térképi adatai az érintett önkormányzat térinformatikai rendszeréból kerülnek megjelenítésre a felhasználó igényei szerint. A felhasználó a következô téradatok közül válogathat:

- földmérési alaptérkép, ami az ingatlan-nyilvántartási állapotot rögzíti,

- utcatérkép, ami az ingatlannak a településen belüli elhelyezkedését, megközelíthetőségét szemlélteti,

- ortofotó, ami az ingatlan természetbeni állapotát mutatja,

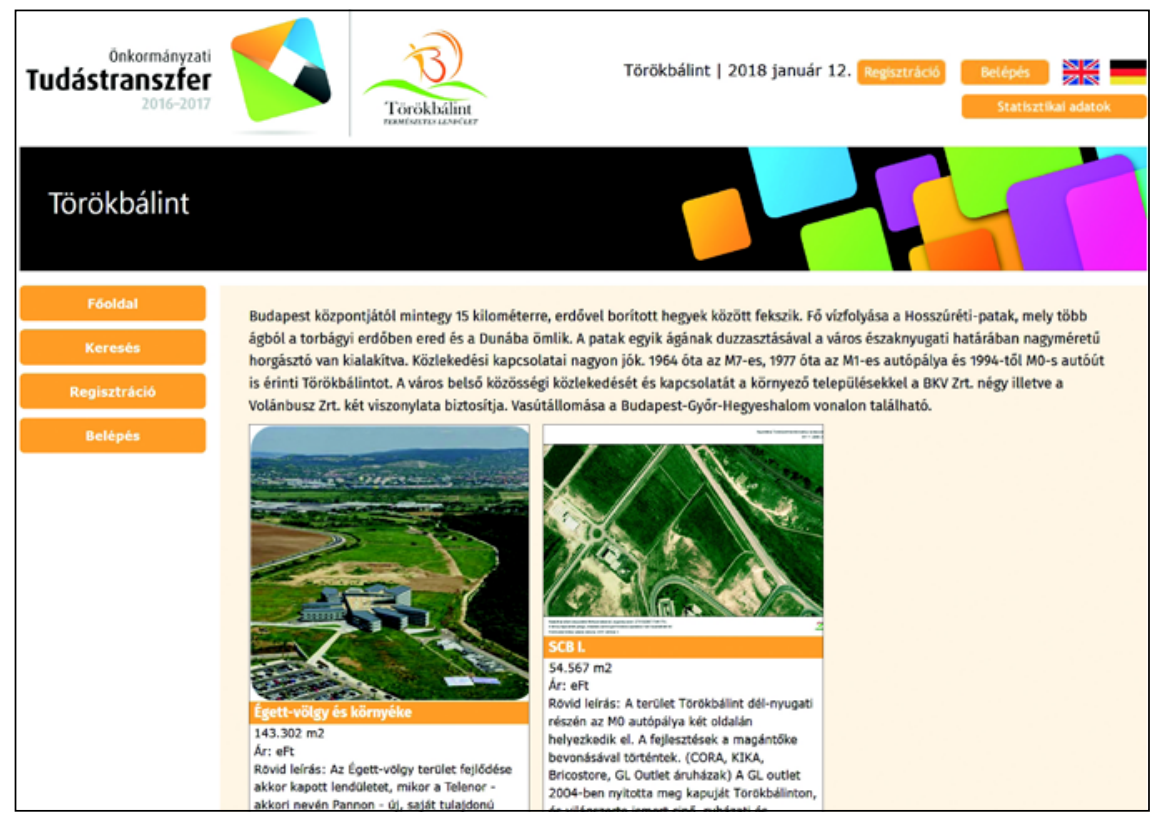

3. ábra. Törökbálint település portfóliójának nyitó oldala

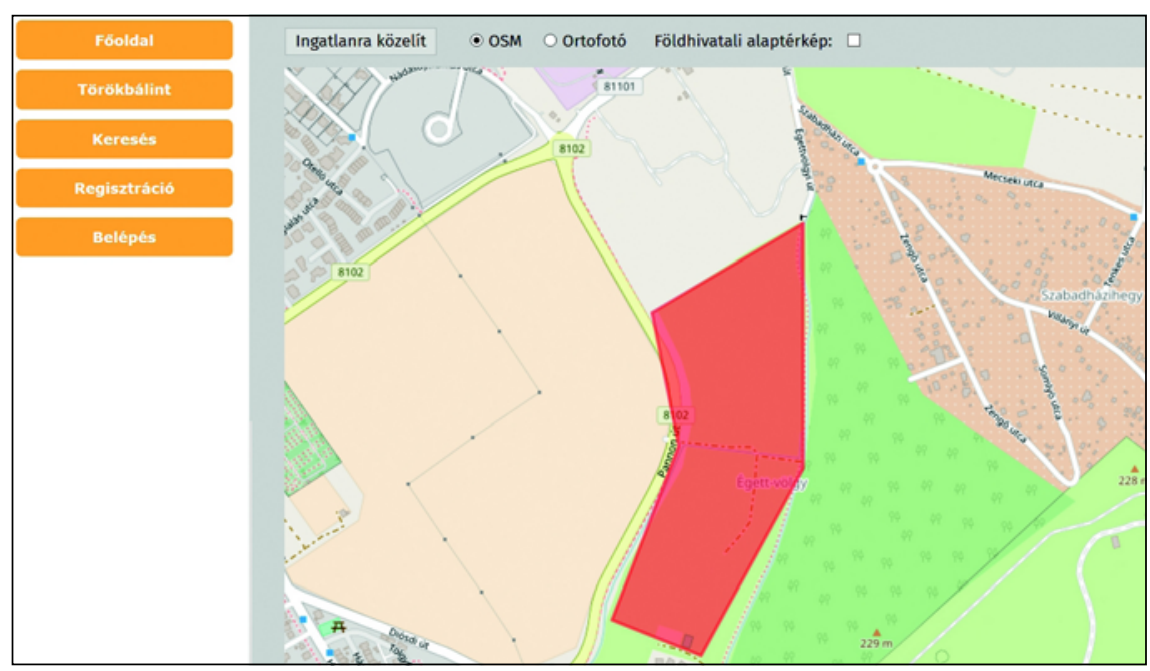

4. ábra.A portfólióból kiválasztott ingatlan térképi adatai
- közmútérképek, amelyek az ingatlan közmúellátottságát mutatják meg. A felhasználó által összeállított térkép az adatlappal együtt kinyomtatható.

A portfólió kiadványszerú megjelenítése érdekében minden ingatlanról egy előre összeállított, három tematikus részből álló ismertetố nyomtatható ki, az alábbiak szerint:

- Az elsố rész az ingatlan adatlapjának adatait tartalmazza.

- A második részt az ingatlanhoz csatolt, pl. távoli, közeli fotók képezik.

- A harmadik részt pedig a térképrészletek alkotják, amelyek az ingatlan közvetlen környezetét mutatják be a településen belül, illetve pl. Törökbálint elhelyezkedését a régióban.

A rendszer adatbázisai jelenleg feltöltés alatt állnak. A KIBIR a http://kibir. normaproject.hu címen érhetô el.

\section{Okos Közösség - Okos Város - Okos Régió}

Az elsôdleges cél az érintett településeken az Okos Közösség (Smart Community) kialakulása, amely létrehozza az Okos Régiót. A továbbfejlôdés is adott: okos közösségek okos régióinak, hálózatainak építése és múködtetése.

Az Okos Régió kialakítására rövidtávú cselekvési terv készült. A terv a regionális gazdaságfejlesztés szervezeti háttere kialakításának lépéseit fogalmazta meg, ezek:

- 5T-modell elfogadása,

- gazdaságfejlesztési koordináló bizottság létrehozása,

- éves munkaterv összeállítása,

- befektetéstámogatási információs rendszer létrehozása, múködtetése,

- településenkénti ingatlanbefektetési portfólió összeállítása,

- önkormányzati döntéstámogató információs rendszer bevezetése,

- e-learning továbbképzés önkormányzati munkatársaknak,

- e-learning továbbképzési tananyag kifejlesztése mikro-, kis- és közepes vállalkozásoknak.

A terv megvalósítása sikerességének feltétele, hogy az érintett települések képviselő-testületei elfogadják a 
stratégiai modellt, a cselekvési tervvel együtt, és támogassák a végrehajtását. Ez 2017 novemberében megtörtént.

\subsection{Okos megoldások alkalmazása}

Az okos technológiák alkalmazásának, összekapcsolásának folyamata elkezdôdött az érintett településeken. Törökbálinton a Gazdasági Program (2015-2019) által lefedett ötéves ciklus 2016-2017. évi tervei fókuszálnak elsôsorban erre a tevékenységre. Természetesen ezen technológiák alkalmazásához az innovatív térinformatikai megoldásokon kívül a lakosság, a vállalkozók digitális kompetenciáinak fejlesztésére is szükség van. Ezt támogatja többek között a térségi e-learning és élethosszig tartó tanulás kampányai mellett, a kormányzat Digitális Jólét Programja is.

Az alábbiakban néhány - alkalmazásba vett - okos megoldást sorolunk fel:

- TörökbálintMa applikáció - okos telefonon elérhetô helyi hírújság.

- Torokbalintbejelento applikáció közterületi károkozások (pl. illegális hulladéklerakás, kátyúk, buszmegálló-rongálás, parlagfüves terület) bejelentése okostelefonon, térinformatikai támogatással,

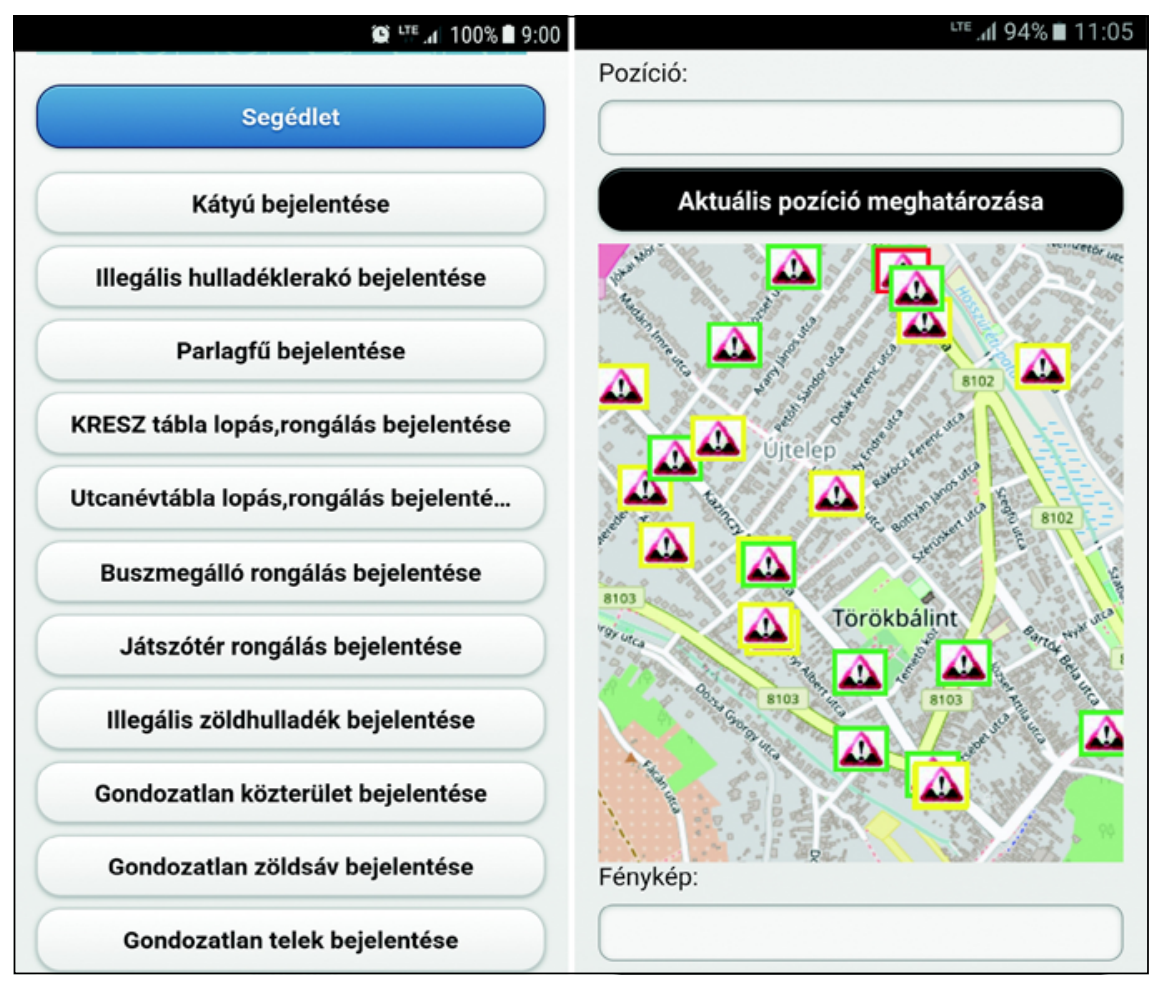

5. ábra. Az applikáció kezelófelülete
- telek- és építményadó-bevallás ellenôrzése térinformatika segítségével,

- önkormányzati beruházások kockázatelemzése,

- közterület-felügyelet térinformatikai támogatással,

- intelligens térfigyelô rendszer.

Az 5. ábra a Torokbalintbejelento app okostelefon-alkalmazás kezelófelületét mutatja.

Kiemelnénk, hogy az okos megoldások kezeléséhez okos lakosok, ügyintézók kellenek, akik megfelelő digitális kompetenciákkal rendelkeznek.

\section{6. Összegzés}

A kistérségi gazdaságfejlesztési modell megvalósítása, az Okos Régió kialakítása több éves folyamat. Tanulmányunkból kitûnik, hogy az eredményes megvalósításuk fontos eleme a térinformatika alkalmazása, amelynek lehetôségei még koránt sincsenek teljesen kihasználva.

Úgy gondoljuk, hogy az okos város és régió (térség) megvalósításában Törökbálint és térsége kedvezố helyzetben van. Időben indultak el a fejlesztések és a szükséges infrastrukturális és egyéb feltételek - IT infrastruktúra, térinformatikai rendszer, stratégiák, tervek stb. - biztosítása. Ezt támasztja alá a 1456/2017. (VII. 19.) korm.-határozat a Nemzeti Infokommunikációs Stratégia (NIS) 2016. évi monitoring jelentésérôl... 20. pontja, mely szerint a kormányzat „kiemelkedöen fontosnak tartja a helyi, települési és térségi közösségek digitális fejlesztési programjainak, illetve az Okos Város (Smart City) fejlesztések támogatását, ezért elrendeli egy Okos Város munkacsoport, illetve Okos Város és Okos Térség közigazgatási mintaprojekt létrehozását, valamint az Okos Város megoldások megjelenitését a kormánytisztviselói és köztisztviselói képzésekben."

\section{Irodalom}

1. Niklasz L.: Törökbálint a digitális városból intelligens várossá válás útján. Geodézia és Kartográfia 2015/9-10.

2. Pro Régió Kft.: Törökbálint és térsége - kistérségi gazdaságfejlesztési modell Megalapozó tanulmány (helyzetfelmérés) Budapest, 2016. szeptember

3. Pro Regió Kft.: Törökbálint és térsége - kistérségi gazdaságfejlesztési modell. Koncepció és stratégia. Budapest, 2017. február

4. Törökbálint Város Önkormányzatának Gazdasági Programja 2015-2019. Önkormányzati stratégiai dokumentum. Törökbálint, 2015. április

5. Niklasz L.: Törökbálint Város Befektetés-ösztönzési Stratégiai Terve. Önkormányzati stratégiai dokumentum. Törökbálint, 2016. május

6. KaraS.-Devecseri A.:Területi és Települési Tervezést Támogató Rendszer (4TR). Lechner Tudásközpont. Tudástranszfer az e-learningrốl és az e-kormányzásról konferencia prezentáció, Törökbálint, 2017. október 24.

7. Kassai F: E-government megvalósításának feltételei. Budapesti és Pest Megyei Mérnökkamara. Tudástranszfer az e-learningrôl és az e-kormányzásról konferencia prezentáció, Törökbálint, 2017. október 24.

8. Kelemen Cs.: Smart City feltételei. Nemzeti Fejlesztési Minisztérium. Tudástranszfer az e-learningrốl és az e-kormányzásról konferencia prezentáció, Törökbálint, 2017. október 24 .

\section{Summary}

The municipality of Törökbálint has developed a micro-regional economic development model in cooperation with 4 other local governments. The model combines regional economic development with the creation of a Smart Region. The authors emphasize that the first step towards achieving 
this goal is the creation of smart citizens' communities, and the creation of smart cities based on this.

Smart cities form the Smart Region that can be created in a mosaic manner, as digitization enables multiple settlements in space and time to innovate and resilient economic development cooperation.

The study lists the benefits of creating a Smart Region.

The authors point out that digitization in this process has a decisive role. The study further deals with the role of GIS in local and regional economic development and in the realization of the smart city/region. This is illustrated by practical examples. In local economic development for example, the local government of Törökbálint has e-land registry\&cadastre, e-public utility registration system, urban plans, DTM, orthophoto, street map based on geoinformatics and has a decisionsupporting IT system based on these. Regional economic development is supported by an investment incentive information system based on the real estate portfolio of the local governments concerned.

Subsequently, the study presents the steps for the creation of a Smart Region and the model. The emergence of a smart citizen can lead to e-learning, lifelong learning and digitization. The 5 municipalities that make up the micro-region have developed special e-learning modules and have an educational web portal.

Applying smart solutions to the development of a smart city. The authors list some of the solutions that use geospatial methods, eg. control of building and land tax returns, residential announcements of environmental damage, intelligent surveillance system.
The Hungarian government supports the formation of smart city, smart region and the training of civil servants in that direction.

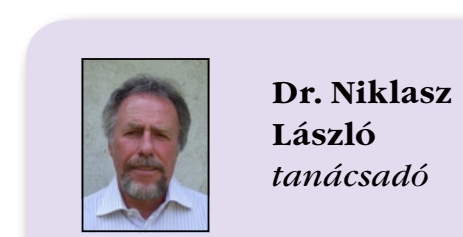

Törökbálint Város Önkormányzat niklasz.laszlo@torokbalint.hu

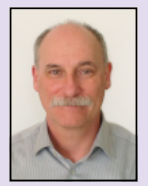

Varga-Ötvös Béla

ügyvezetố

Értéktérkép Kft. vob@ertekterkep.hu 